Available online at Dakwah: Jurnal Kajian Dakwah dan Kemasyarakatan http://journal.uinjkt.ac.id/index.php/dakwah

Dakwah: Jurnal Kajian Dakwah dan Kemasyarakatan, 24 (2), 2020, 145-157

\title{
Dakwah Ulama Dalam Menjaga Toleransi Beragama Di Wilayah Kota Tangerang Selatan Dan Depok
}

\author{
Deden Mauli Darajat \\ Universitas Darussalam (UNIDA) Gontor \\ kangdedenmd@gmail.com \\ Rubiyanah \\ UIN Syarif Hidayatullah Jakarta \\ rubiyanah@uinjkt.ac.id
}

\begin{abstract}
Religious conflicts often occur due to the unfair implementation of religious preaching which tend to obtrude. This form of preaching clearly contradicts the nature of religion which demands peace, coexistence and respect for human rights. This research explores in depth the extent to which the da'i provide enlightenment to the community so that they can live side by side and in harmony with followers of other religions. Islam is a religion that carries out the mission of rahmatan lil 'alamin, so it must be an inspiration and a carriage in bringing a tolerant life for the universe. Therefore, in preaching, preachers must prioritize preaching that is tolerant and wise, so that Islam can be accepted in the midst of a plural society. This research uses descriptive method with qualitative data analysis.
\end{abstract}

Keywords: role, da’i, dakwah, religious tolerance

\begin{abstract}
Abstrak
Konflik keagamaan seringkali terjadi akibat pelaksanaan penyiaran agama yang tidak fair dan cenderung memaksakan kehendak dalam beragama. Bentuk dakwah ini, jelas bertentangan dengan fitrah agama yang menghendaki kedamaian, hidup berdampingan, mendapatkan penghormatan atas hak-hak asasi manusia. Penelitian ini menggali secara lebih mendalam tentang sejauhmana para da'i memberikan pencerahan kepada masyarakat agar dapat hidup berdampingan dan harmonis dengan penganut agama lain. Islam adalah agama yang mengemban misi dakwah rahmatan lil 'alamin, sehingga harus menjadi inspirasi dan gerbong dalam menyongsong kehidupan yang toleran bagi semesta alam. Karena itu, di dalam berdakwah, däi harus mengedepankan dakwah yang toleran dan bijaksana, sehingga Islam dapat diterima di tengah-tengah masyarakat yang plural. Penelitian ini menggunakan metode deskriptif dengan analisis data kualitatif.

Kata kunci: peran, da’i, dakwah, toleransi beragama.
\end{abstract}

Permalink/DOI: http://doi.org/10.15408/dakwah.v24i2. 18339

\section{Pendahuluan}

Dalam konteks sosiologis, kehidupan keagamaan dapat diwujudkan pada bentuk toleransi atau kerukunan hidup antar umat beragama. Di Indonesia, kerukunan umat beragama 
merupakan bagian yang esensial dari pembinaan persatuan dan kesatuan nasional. Pada Pasal 29 ayat (2 )UUD 1945 dinyatakan: "Negara menjamin kemerdekaan tiap-tiap penduduk untuk memeluk agamanya masing-masing dan untuk beribadat menurut agamanya dan kepercayaannya itu”.

Dimensi agama merupakan salah satu dimensi kehidupan paling vital di Indonesia. Hal ini dapat dimaklumi, karena rakyat Indonesia begitu patuh terhadap ajaran agama. Tidak hanya Islam, tetapi juga Kristen, Katolik, Hindu dan Budha. Keberagamaan dan keyakinan seperti demikian tidaklah bermasalah, selama agama dan kepercayaan yang dianut atas dasar ketukan nurani, bukan karena paksaan serta intimidasi. ${ }^{1}$

Merujuk laporan tahunan The Wahid Institute, bahwa selama JanuariDesember 2013, jumlah pelanggaran atau intoleransi keyakinan beragama tercatat 245 peristiwa, yang terdiri: 106 peristiwa (43\%) melibatkan aktor negara dan 139 peristiwa (57\%) aktor non negara. Sementara total jumlah tindakan kekerasan dan intoleransi mencapai 280 kasus, yaitu: 121 tindakan (43\%) dilakukan aktor negara dan 159 tindakan (57\%) oleh aktor non negara. ${ }^{2}$

Kasus penolakan pembangunan gereja Yasmin di bogor, pembakaran masjid di Tolikara Papua, pengusiran terhadap penganut Gafatar, penolakan terhadap kaum Syiah di Madura dan Ahmadiyah di Kuningan Jawa barat serta penolakan pembangunan masjid di Manado menambah panjang deret kasus intoleransi beragama di Indonesia.
Penolakan terhadap Ahok menjadi gubernur DKI Jakarta yang oleh sebahagian orang dianggap sebagai bentuk intoleransi adalah kasus yang paling menyedot perhatian sepanjang tahun 2016-2017.

Persoalan agama adalah persoalan yang paling peka dan sensitif, apalagi jika dipolitisasi. Merealisasikan prinsip "Agree In Disagreement" atau setuju dalam perbedaan bukanlah hal yang mudah, namun para tokoh agama senantiasa berusaha mencari solusi yang tepat untuk kepentingan bersama berupa terwujudnya kedamaian dan harmoni.

Pemahaman yang keliru terhadap dakwah menjadi titik rawan yang dapat mendorong terjadinya konflik. Dakwah yang dipahami sebagai suatu aktivitas menyeru serta mengajak orang yang berlainan agama agar secara langsung mengkonversikan keyakinannya, hanyalah akan memancing timbulnya pertikaian dan perpecahan di antara pemeluk agama. Untuk itu, para da’i atau missionaris dalam melakukan aktivitas penyebaran agama harus menghindari efek negatif, yakni upaya memaksakan kehendak memeluk agama. ${ }^{3}$ Ini dimaksudkan agar dalam praktik penyebaran agama tidak terjadi "penghalalan segala cara" demi mencapai tujuan dakwah/misi tersebut.

Dengan demikian, sangat diperlukan wawasan konseptual tentang dakwah, sehingga kemungkinankemungkinan terjadinya konflik di antara pemeluk agama akan teratasi. Di dalam al-Qur'an terdapat pernyataan kalimat: نعالوا إلى كلمة سواء (mari kita bertemu dalam satu kalimat yang sama), yaitu iman 
kepada Allah dan amal saleh. ${ }^{4}$ Pada ayat lain juga disebutkan: "Bagimu agamamu dan bagiku agamaku”.5 Ini berarti bahwa Islam telah menerapkan sikap setuju dalam perbedaan (agree in disagreement).

Fakta sejarah membuktikan, toleransi dalam kehidupan beragama merupakan bagian dari aplikasi dakwah Rasulullah saw pada periode Madinah. Kebebasan memeluk agama dijadikan sebagai prinsip sentral, sebab masyarakat Madinah sangat heterogen khususnya di bidang agama. Untuk itulah Rasulullah saw mendirikan negara atas dasar prinsip-prinsip kesamaan, kebebasan dan persaudaraan.

Masyarakat Madinah yang plural dan heterogen, ternyata mampu hidup berdampingan di bawah pimpinan Rasulullah saw dengan dilandasi oleh sebuah konstitusi, ${ }^{6}$ walaupun akhirnya penanaman sikap toleransi ini gagal diterapkan setelah mendapat respon negatif dari kaum Yahudi. Namun demikian, sejarah telah membuktikan bahwa umat Islam dengan kaum Yahudi pada awalnya hidup berdampingan secara damai. Karena masalah politiklah mereka berkonflik, dan ini tidak mengendurkan upaya Rasul dalam menanamkan sikap toleransi beragama.

Berdasarkan uraian tersebut dapat ditegaskan bahwa Rasulullah saw dalam melakukan dakwahnya sangat memerhatikan kerukunan antar umat beragama. Sikap toleransi selalu ditanamkan Rasul kepada umat Islam agar mampu hidup berdampingan dengan sesamanya yang memeluk agama lain. Salah satu contoh kongkrit tercermin dalam sabdanya: "Barangsiapa mengganggu seorang Dzimmi berarti akulah lawannya, dan barangsiapa yang menjadi lawanku, niscaya ia akan dikalahkan kelak di hari kiamat”. (Riwayat alKhatib). ${ }^{8}$ Pernyataan hadits ini sejalandengan penegasan al-Qur'an yang artinya:

Atas dasar itu, dibutuhkan pemahaman para da'i mengenai hakikat berdakwah yang diupayakan kepada penegasan "cara melakukan dakwah", yakni penekanan terhadap kesadaran bahwa kewajiban berdakwah pada dasarnya hanya memberi peringatan, tidak dibebankan untuk mengubah sikap orang lain, sebab Allahlah yang memiliki kemutlakan otoritas tersebut. 9

Redefinisi tentang dakwah yang saat ini masih terfokus pada pemahaman "mengajak orang lain yang berbeda agama agar mengkonversikan keyakinannya", sangat diperlukan. Dampak dari pemahaman yang keliru mengenai arti dakwah mengakibatkan munculnya praktik dakwah yang berorientasi pada paksaan untuk mendapatkan pengikut sebanyakbanyaknya. Ini jelas bertentangan dengan prinsip al-Qur'an yang melarang melakukan paksaan dalam beragama. ${ }^{10}$

Peran para da'i sangat dibutuhkan untuk memberikan pencerahan kepada para mad'u (obyek dakwah) agar tetap bisa menjaga hidup berdampingan yang harmonis dengan penganut agama lain. Islam adalah agama dakwah yang mengemban misi sebagai rahmatan lil 'alaminuntuk menjadi inspirasi dan gerbong dalam 
menyongsong kehidupan yang toleran bagi semesta alam. ${ }^{11}$ Karena itu, di dalam berdakwah, da'i harus mengedepankan dakwah yang toleran dan bijaksana, sehingga Islam dapat diterima di tengahtengah masyarakat yang plural.

Permasalahan dalam penelitian ini adalah ingin menjawab persoalan mengenai bagaimana peran dai dalam menjaga toleransi beragama di tangerang selatan yang diturunkan pada beberapa pertanyaan minor yakni: Bagaimana upaya internal dan ekternal dai dalam menjaga toleransi beragama? Bagaimana harapan masyarakat terhadap peran dai dalam menjaga toleransi beragama di wilayah Tangerang Selatan?

\section{Literatur Review}

Penelitian mengenai toleransi dan agama salah satunya ditulis oleh $\mathrm{M}$. Chairil Anwar dan Muhammad Afdillah tentang "Peran Ulama Di Nusantara Dalam Mewujudkan Harmonisasi Umat Beragama" ${ }^{12}$ Penelitian ini mengangkat permasalahan tentang bagaimana Islam masuk di Nusantara, bagaimana peran ulama dalam mewujudkan harmonisasi beragama dan apa kontribusi keilmuan peran ulama bagi masa depan Islam di Nusantara. Penelitian Ali Muhtarom yang berjudul "Peran Ulama Dalam Menangkal Radikalisme Agama Di Kabupaten Batang Jawa Tengah". ${ }^{13}$ Penelitian ini mencoba mendeskripsikan peranan ulama dan kyai dalam menangkal radikalisme agama serta memberi gambaran bagaimana para ulama dan kyai memberikan pendidikan keagamaan kepada masyarakat khususnya pemahaman agama di wilayah
Kabupaten Batang. Penelitian Nuwaerah tentang "Dakwah di Tengah Keragaman Umat”, meyimpulkan bahwa mewujudkan suasana harmoni pada masyarakat Indonesia yang teramat beragam memerlukan kebersamaan berbagai pihak, termasuk masyarakat da'i, yang memikul tanggung jawab untuk merefleksikan nilai-nilai kerahmatan dalam segenap aspek kehidupan manusia. Melakukan pendekatan dakwah yang kreatif dan inovatifmerupakan tantangan tersendiri bagi para da’i yang dituntut untuk mencermati danmemahami realitas masyarakat Indonesia yang beragam tersebut. ${ }^{14}$ Penelitian Abersold, G.W. berjudul Word to Think About Tolerance of Religion, membahas tentang konsep toleransi dalam semua agama baik Hindu, Budha, Islam, Yahudi, maupun Kristen. Konsep toleransi yang dimaksud oleh Abersold mencakup aspek kehidupan manusia. ${ }^{15}$

\section{Landasan Teori}

Toleransi beragama dalam masyarakat melalui keberperanan da'i, dikaji dengan menggunakan teori peran. Menurut teori tentang peran, struktur sosial individu tertentu memiliki peran sosial yang memiliki serangkaian hak, kewajiban, harapan, norma dan seterusnya. Setiap individu bertindak dengan cara yang dapat diprediksikan, perilaku individu bergantung pada konteksnya, berdasarkan posisi sosial dan faktor-faktor lain. ${ }^{16}$

Teori peran yang muncul tahun 1920-an dan 1930-an ini dikembangkan melalui karya teoretis Mead, Moreno, 
dan Linton. Mead menititikberatkan pada dua hal, yaitu pikiran dan diri sendiri. Perilaku sosial masyarakat merupakan obyek kajian dari teori peran, antara lain:perilaku yang wajar sesuai dengan norma sosial di masyarakat, karena hal itu mampu menentukan harapan; Peran ditempati oleh individu yang disebut "aktor"; Dalam hal perbedaan dalam teori peran, di satu sisi ada sudut pandang yang lebih fungsional, yang dapat dibedakan dengan pendekatan tingkat lebih mikro berupa tradisi interaksionis simbolis. Jenis teori peran ini menyatakan bagaimana dampak tindakan individu yang saling terkait terhadap masyarakat, serta bagaimana suatu sudut pandang teori peran dapat diuji secara empiris. Kunci pemahaman teori ini adalah bahwa konflik peran terjadi ketika seseorang diharapkan melakukan beberapa peran sekaligus yang membawa pertentangan harapan. ${ }^{17}$

Da'i adalah orang yang melaksanakan dakwah, baik dengan lisan, tulisan maupun perbuatan yang dilakukan secara individu, kelompok, atau melalui organisasi/lembaga. ${ }^{18}$ Da'i sering juga disebut dengan muballigh, yakni orang yang menyampaikan ajaran Islam. Namun sebutan muballigh ini konotasinya sangat sempit, karena masyarakat cenderung mengartikannya sebagai orang yang menyampaikan ajaran Islam melalui lisan, seperti penceramah, khatib dan sebagainya.

Dalam menjalankan perannya, da'i dituntut untuk mengetahui segala unsur yang tercakup dalam pelaksanaan dakwah: isi dakwah; unsur manusia yang dihadapi; unsur kondisi (ruang dan waktu); unsur bentuk dan cara dakwah yang sesuai. ${ }^{19}$ Da'i juga harus memiliki tiga faktor yang melekat pada dirinya, antara lain: iman yang kuat, teladan yang baik dan peka terhadap lingkungan sekitar. Dari sinilah, da'i sebagai aktor yang menyampaikan pesan-pesan kebenaran, keberadaannya sangat dibutuhkan masyarakat sesuai dengan harapan, yaitu terciptanya kehidupan yang religius, kondusif serta harmonis, baik dengan sesama muslim maupun non muslim.

Sedangkan toleransi adalah sikap menghargai terhadap pandangan, kepercayaan, tradisi, kultur, perilaku dan lain-lain yang berbeda. $^{20}$ Islam merupakan agama yang toleran, karena ia datang tidak hanya bertujuan mempertahankan eksistensinya sebagai agama, tetapi juga mengakui eksistensi agama-agama lain, dan memberinya hak untuk hidup berdampingan. ${ }^{21}$ Beberapa ayat al-Qur'an menegaskan:

1. "Jangan mencerca yang tidak menyembah Allah (penganut agama lain) ...”. (QS al-An'am/6:108).

2. "Tidak ada paksaan untuk menganut agama (Islam) ...”. (QS alBaqarah/2:256).

3. "Bagimu agamamu dan bagiku agamaku”. (QS al-Kafirun/109:6).

Penegasan al-Qur'an agar umat Islam menjaga toleransi beragama, dipraktikkan oleh Rasulullah saw dalam aktivitas dakwahnya di Madinah, yaitu dengan membuat perjanjian (dustur) yang mengatur kehidupan sesama umat Islam, dan menjelaskan hubungan mereka dengan orang-orang di luar Islam 
secara umum, serta dengan kaum Yahudi secara khusus. ${ }^{22}$ Perjanjian tersebut dikenal dengan Piagam Madinah, terdiri dari 47 butir kesepakatan bersama untuk hidup rukun dan berdampingan.

Mad'u ialah orang yang menerima dakwah, baik sebagai individu maupun kelompok, yang beragama Islam (muslim) atau non muslim. Prof. Dr. Husnul Aqib Suminto mengklasifikasikan mad'u (obyek dakwah) ke dalam empat tingkatan: 1. Masyarakat umum; 2. Masyarakat penguasa; 3. Masyarakat terpelajar; dan 4. Masyarakat desa. ${ }^{23}$ Sementara itu, M. Natsir mengklasifikasikan mad'u kepada tiga golongan: 1. golongan cerdikcendekiawan; 2. Golongan awam; dan 3. Golongan yang tingkat kecerdasannya di antara kedua golongan tersebut.

\section{Metode}

Jenis penelitian ini merupakan penelitian lapangan (field research). Penelitian ini menggunakan pendekatan kualitatif yang bersifat deskriptif analitis dalam penyajian datanya. Metode pengumpulan data dalam penelitian ini menggunakan metode wawancara, observasi dan dokumentasi. Wawancara dilakukan dengan da'i dan pimpinan lembaga keagamaan dan perwakilan masyarakat berkaitan dengan upaya yang dilakukan da'i dalam menjaga toleransi bergama di wilayah Tangerang Selatan.

Dikarenakan penelitian ini menggunakan pendekatan kualitatif, maka subyek penelitian ini disebut informan, yakni orang-orang yang mewakili karakteristik pada domain dakwah, yakni da'i dan pimpinan lembaga keagamaan serta masyarakat sebagai mad'u (obyek dakwah).Sedangkan Objek penelitiannya adalah upaya yang dilakukan dai dalam menjaga toleransi beragama di wilayah Tangerang Selatan.

Teknik pengumpulan datanya dengan observasi ke beberapa wilayah di Kota Tangerang Selatan, selanjutnya dengan melakukan wawancara kepada para da'i, masyarakat sebagai perwakilan mad'u yang representatif. Serta dokumentasi berupa catatan lapangan dan rekaman isi ceramah da'i. Instrumen dalam penelitian ini adalah peneliti sendiri sedangkan alat bantu peneliti adalah pedoman wawancara. Tehnik pemeriksaan keabsahan data dengan metode triangulasi, yakni melakukan pengecekan derajat kepercayaan suatu informasi pada sumber data), ${ }^{24}$ dalam hal ini adalah hasil wawancara antara informan yang satu dengan informan lain (da'i , pimpinan lembaga keagamaan dan tokoh masyarakat.

Teknik analisa data menggunakan tehnik analisis data kualitatif model domain, yakni mengklasifikasikan data berdasarkan lokasi, alasan, atribut atau karakteristik, sebab akibat, tujuan, dan fungsi. Tehnik ini digunakan karena penelitian ini bertujuan atau bersifat eksploratif dengan penyajian data deskriptif. ${ }^{25}$

\section{Temuan}

Penduduk Kota Tangerang Selatan berasal berbagai suku dan budaya. Penduduk asli adalah Betawi, Sunda dan sisanya adalah masyarakat perkotaan datang dari berbagai daerah. ${ }^{26}$ 
Penduduk Tangerang Selatan berdasarkan populasi agama yang dianut oleh setiap masyarakat, Islam adalah 902.282 orang, Kristen sebanyak 58.237 orang, Katolik 41.185, Hindu 24.384 orang, Budha sebanyak 13.844 orang, Konfusius sebanyak 1974 jiwa dan aliran percaya sebanyak 120. Dari jumlah ini mayoritas Populasi Kota Tangerang Selatan memeluk Islam sebagai sebanyak 86,59\%. Selama tahun 2009 tercatat jumlahnya fasilitas keagamaan di kota Tangerang Selatan adalah 497 masjid 1.015 mushalla, 40 gereja, 3 pura, 6 vihara, dan 2 candi.

Nuansa Islami lebih mewarnai kehidupan masyarakat Kota Tangerang Selatan, ini karena jumlah Umat Islam yang mencapai hampir 90 persen, begitu harmonis antar agama sejauh ini, tidak menjadi kendala. Ini bisa terlihat dalam kondisi koeksistensi yang tenang dan damai itu telah ada selama ini. Oleh karena itu perlu upaya untuk mempertahankan toleransi beragama yang telah berjalan dengan baik hindari induk dan sikap yang dapat merusak kehidupan yang harmonis di antara para pengikut agama yang telah berlangsung lama di wilayah tersebut.

Tidak terlalu berbeda dengan Tangerang Selatan, para Penduduk Kota Depok berdasarkan agama yang dianut Islam sebanyak 1. 853.898, Kristen 105. 218, Katolik 35.401, Hindu menghitung 40.001, Budha sebagai sebanyak 6. 718, Konfusius 2.255 dan lainnya hingga 120 orang. Dari jumlah ini mayoritas penduduk Depok memeluk Islam sebanyak 91, 16\%. Selama tahun 2014 mencatat jumlah fasilitas keagamaan di beberapa layanan keagamaan di kota Depok sebanyak masjid 4.216, mushola 1.406 , gereja 132 , pura 5 , dan vihara $2 .{ }^{27}$

Beberapa ulama yang mewakili wilayah Selatan Kota Tangerang sepakat bahwa menjaga kerukunan beragama adalah bagian penting dalam kegiatan dakwah. Demikian dakwah harus memberikan kontribusi positif kepada masyarakat di Indonesia dengan menanamkan toleransi di antara umat beragama. Peran dari ulama dan da'i adalah menentukan gaya dakwah diterima oleh umat, apakah harus dengan memaksakan kehendak dari keyakinan yang berbeda untuk mengubah keyakinan agama mereka, atau dengan bijak membawa ajaran agama sesuai dengan petunjuk Al-Qur'an dan Sunnah tanpa memaksakan kehendak terhadap mad 'u (objek dakwah) di antara Muslim dan nonMuslim.

Ulama ibarat lampu yang harus ada di dalam komunitas untuk menerangi kehidupan. Objek yang diterangi tentu saja heterogen: agama, etnis dan ras. Karena kondisi ini, ulama harus memilih yang cocok tema dan tidak ofensif terkait dengan beberapa suku, agama, ras, dan di antara kelompok-kelompok ketika menyampaikan dakwah di hadapan para audiens yang heterogen. Berkaca pada dakwah yang dilakukan oleh Rasulullah, hal yang perlu diperhatikan adalah keakuratan Nabi dalam membina dan merekatkan hubungan antar masyarakat. Mulai dari orang terdekat, lalu makin lama makin luas. Antara kelompok muhajirin (Mekah) dan Ansar di 
Madinah, direkatkan oleh Nabi dengan mengikat beberapa 'orang kunci' setiap kelompok menjadi saudara. Bahkan di antara kelompok besar Muslim dengan kelompok Yahudi juga terpaku bersama untuk menjaga integritas dan ketahanan kota Madinah. Ditekankan dalam Piagam Madinah point ke-44: "Semua warga negara akan bekerja sama dalam menghadapi pihak lain yang meluncurkan serangan terhadap Yathrib.”

Begitu juga dengan media, dakwah juga mengikuti perkembangan pesan yang cepat dan penggunaan media, terutama media sosial (medsos). Beberapa ulama menggunakan ini sebagai media untuk menyampaikan dakwah. Objek dakwah di medsos berasal dari berbagai latar belakang dan tidak menutup kemungkinan ada juga yang non-Muslim. Oleh karena itu, materi yang disajikan juga beragam, sehingga dakwah bisa tepat sasaran.

\section{Menyediakan Peluang Ibadah untuk Semua Aliran dan Agama}

Di Kecamatan Sawangan, Kota Depok, Pemerintah dan masyarakat memberikan kesempatan untuk beribadah kepada setiap penganut agama apa pun, meskipun mereka minoritas. Namun, toleransi bukan berarti bebas bertindak seolah tidak ada aturan, karena ada prinsip yang harus dipegang. Karena itu, sekalipun menjunjung tinggi nilainilai toleransi, tetapi ketika ada kasus pendirian rumah ibadah tanpa prosedur yang sesuai dengan ketentuan dan peraturan pemerintah, maka itu tidak bisa dibenarkan. ${ }^{28}$
Kasus demonstrasi umat Muslim atas keberatan pendirian gereja di daerah Pasir Putih Depok, adalah disebabkan karena masalah perizinan pendirian tempat beribadah tersebut. Selain masalah izin pembangunan gereja, kasus intoleransi juga sering terjadi akibat penyumbatan dialog antaragama. Peristiwa mobilisasi massa setelah isu Ahmadiyah di Sawangan, adalah salah satu bukti bahwa komunikasi yang efektif dari para pihak prihatin. Di sini peran ulama sangat mendesak untuk dirintis di garis depan sebagai mediator umat. Kehadiran dari Pemerintah juga sangat diperlukan, karena memiliki kebijakan otoritas yang bisa mengatur arah dan pijakan dalam kehidupan masyarakat, bangsa dan negara. Tentang kasus penolakan pembangunan gereja, $\mathrm{KH}$. Mahfudz Anwar yang merupakan anggota Forum Kerukunan Umat Beragama (FKUB) Depok, merespons cukup serius. Dia mengatakan bahwa kalau ada proposal untuk pembangunan gereja di wilayah Kota Depok, biasanya meminta rekomendasi dari FKUB Depok. Untuk contoh, pembangunan gereja akan dibangun di wilayah yang didominasi umat Kristen dan sudah ada tanda tangan dari masyarakat di sekitarnya, jadi itu bukan masalah. Namun, jika mayoritas masyarakatnya adalah Muslim, seperti di Beji, maka FKUB tidak menyetujuinya, karena itu tidak sesuai dengan aturan yang berlaku.

Jika di Kota Depok, beberapa tokoh agama masih tampak ambigu dalam menangani penyediaan layanan ibadah untuk aliran tertentu dalam Islam (misalnya kasus Ahmadiyah), dan juga 
untuk non-Muslim, deskripsi masalah ini adalah merespons sedikit berbeda oleh Ketua Majelis Ulama Indonesia (MUI) Tangerang Selatan, K.H. Muhammad Saidi. Menurutnya, beribadah di Indonesia sesuai dengan aliran dan kepercayaan itulah yang menjadi hak masing-masing penganut agama, jadi jangan sampai terhalang. Karena Indonesia adalah negara berdasarkan Pancasila, bukan negara berdasarkan satu agama. Sebagai seorang ulama dan da'i, Kyai Saidi selalu menekankan pentingnya kebebasan beragama, bukan agama tunggal meskipun mayoritas (seperti Islam) menekan orang lain dan mencegah mereka beribadah, termasuk membangun rumah ibadah selama mereka tidak melanggar aturan yang ditetapkan oleh pemerintah.

\section{Membuka Dialog Antar Umat Beragama}

Pertemuan tokoh lintas agama di Kota Depok sering dilakukan oleh FKUB. Selain menjadi salah satu program dari FKUB, pertemuan itu juga merupakan tempat keramahtamahan antar tokoh agama. Dalam konteks dialog, KH. Zainuddin Anwar, salah satu ulama karismatik Kota Depok, sebagai pelopor dialog antaragama. Bahkan Kyai yang menjadi pengasuh Pondok Pesantren AlHamidiyah Depok, sering dikunjungi oleh pendeta dan pemimpin agama lain di rumahnya berdekatan dengan asrama sekolah.

Dialog antara umat beragama harus digunakan sebagai forum untuk kerukunan beragama yang bisa menjembatani berbagai masalah yang timbul dari masalah keagamaan di Indonesia. Dari sini dialog tidak hanya berfungsi untuk mencari kesepakatan, tetapi juga kontrol terhadap kegiatan yang dianggap destruktif dalam kehidupan beragama. Keberadaan dialog sangat penting sebagai upaya untuk menghindari sikap intoleransi agama. Karena itu, dialog tidak hanya dilakukan antar agama, tetapi juga antar mazhab dalam agama. Dalam kasus ini, Dialog internal dan eksternal pada agama harus dilakukan secara intensif dan terus menerus, untuk menghindari intoleransi dalam masyarakat. Pada kenyataannya, dialog internal keagamaan adalah lebih sulit daripada dialog eksternal.

Majelis Ulama Indonesia (MUI) Kecamatan Pamulang Kota Tangerang Selatan secara rutin menggelar pertemuan yang mengundang perwakilan NU, Muhammadiyah, dan aliran Abu Jibril. Ini dilakukan untuk meminimalisir terjadinya konlfik internal. Kyai Saidi sebagai ketua umum MUI Kota Tangerang Selatan mengaku malu, jika ada konflik itu terjadi karena masalah agama, terutama masih dalam satu agama.

Berdasarkan hasil wawancara dengan beberapa tokoh agama, semua pihak yang terlibat dalam dialog forum harus menyadari bahwa ada bidang kepercayaan yang sulit untuk didamaikan, ini juga akan menghasilkan ketegangan, hubungan retak yang menghambat proses dialog. Jadi langkah paling tepat dalam membangun kebersamaan di antara umat beragama adalah berdialog untuk membahas hal tersebut dan di saat yang sama mencari 
solusi yang efektif untuk sejumlah kasus yang dianggap membahayakan keharmonisan kehidupan beragama.

Dari hasil analisis yang ada, juga ditemukan bahwa sampai sekarang peran ulama dalam memelihara agama toleransi di Tangerang Selatan dan Kota Depok masih jauh dari ideal. Ini juga terlihat dari data dan hasil wawancara dengan masyarakat bahwa mereka masih berharap ulama bisa menjadi garda depan dalam menjaga toleransi beragama bahkan antaragama. Berikut ini adalah harapan publik kepada para ulama.

\section{Ulama Harus Memiliki Kredibilitas}

Ulama adalah kumpulan orang yang memiliki pengetahuan di bidang ilmu syariah: fiqh, tafsir, hadis, monoteisme, kalam, akhlak, tasawuf, dan sebagainya dan ia adalah seorang Muslim. Karena itu, seseorang yang berpengetahuan luas dalam Islam tapi bukan Muslim, maka statusnya bukan ulama, tapi seorang ilmuwan. Ulama adalah orang yang memiliki kualifikasi pengetahuan, sehingga membawa dirinya memiliki sifat khasyyah (takut) hanya untuk Allah SWT saja. Dalam hadits disebutkan, bahwa ulama adalah pewaris para nabi (al'ulama waratsat alanbiya ').

Selain kemampuan yang disebutkan di atas, saat ini, seorang ulama harus memegang dan mengikuti perkembangan teknologi, jadi dia pintar serta melihat apa pun informasi yang berkembang. Diperlukan seorang ulama memahami perkembangan masyarakatnya. Di zaman modern di dunia saat ini, seorang ulama tidak bisa begitu saja mengeksplorasi ilmu syariah, tafsir atau hadits saja, terutama jika itu pengetahuan hanyalah penghafalan.

Untuk mengatasi tantangan dan masalah sekarang dan masa depan, perlu untuk mengatasi penuh dan ilmu-ilmu Islam yang dinamis, di samping alat-alat dari sains dan wawasan yang dapat digunakan untuk memahami pengembangan masyarakat. Dengan demikian, ulama selalu dapat menyediakan bimbingan dan arahan yang bisa diterima, tidak ketinggalan atau terperangkap oleh pemahaman agama yang statis dan wawasan yang sempit.

\section{Ulama Harus Melindungi}

Ulama sejatinya sebagai sosok yang harus bisa meredam suasana jika terjadi permasalahan di masyarakat. Misalnya, masalah yang berkaitan dengan pemilihan Gubernur DKI Jakarta, Ahok pada 2017. Banyak masalah yang berasal dari sumber yang tidak jelas kebenarannya yang sengaja dibuat untuk memecah belah masyarakat.

Salah satu warga Kota Depok mengekspresikannya kritik dan harapan terhadap ulama, ada ulama yang berapiapi dalam mengungkapkan pendapat, tetapi isinya sangat provokatif dan kurangnya pengetahuan. Seharusnya ulama punya wawasan luas, moderat, berpikiran terbuka, dan tidak mudah terbawa arus. Apalagu jika mengarah kepada masalah yang berkaitan dengan suku, adat, ras, dan agama (SARA).

Pendapat warga Depok di atas tidak berbeda dengan warga yang 
berdomisili di Kota Tangerang Selatan, yang berharap orang bisa merasakan kedamaian setelah mendengarkan nasihat ulama, bukan sebaliknya. Seorang ulama juga harus tegas, tidak keras dalam mengatakan dan menasihati. Dalam hal ini, para ulama harus menjadi pemersatu umat, bahwa perannya dalam membina dan membimbing para pengikut aliran sesat kembali ke jalan yang benar, memediasi (perdamaian) antara pihak yang bertikai dan perselisihan di antara umat, sehingga perselisihan dan perpecahan dapat dihindari atau diminimalkan.

\section{Penutup}

Peran ulama dalam menangani masalah agama adalah hal penting. Di antara peran ulama alam mempertahankan toleransi antar agama, berdasarkan wawancara dari beberapa narasumber di daerah Tangerang Selatan dan Depok adalah ulama harus memperbaiki pola dakwah, ulama harus menyediakan kesempatan untuk beribadah di semua aliran dan agama, dan ulama harus membuka dialog di antara masyarakat agama secara internal dan eksternal. Sementara harapan publik terhadap peran ulama adalah ulama harus memiliki kredibilitas dan dia harus melindungi semua orang dan semua kalangan.

\section{Catatan kaki}

${ }^{1}$ Said Aqil Siradj, Mamang Muhamad Haerudin, Berkah Islam Indonesia: Jalan Dakwah Rahmatan Lil 'alamin, (Jakarta: PT Elex Media Komputindo, 2015), Cet. ke-1, h. 40-41.
${ }^{2}$ Said Aqil Siradj, Mamang Muhamad Haerudin, Berkah Islam Indonesia: Jalan Dakwah Rahmatan Lil 'alamin, h. 146.

3QS al-Baqarah/2:256 menegaskan: "Tidak ada paksaan dalam memeluk agama (Islam), karena sungguh telah jelas jalan yang benar dari jalan yang salah ...”. 4QS Ali Imran/3:64. 5QS al-Kafirun/109:6.

${ }^{6}$ Pasal 16 Piagam Madinah.

7Dzimmi ialah "orang yang tidak beragama Islam dan bernaung di bawah pemerintahan Islam". Lihat Muhammad Tahir Azhary, Negara Hukum, (Jakarta: Bulan Bintang, 1992), Cet. ke-1, h. 122.

8Yusuf Qardhawi, Minoritas Non Muslim, (Bandung: Mizan, 1985), Cet. ke-1, h. 25 .

${ }^{9} \mathrm{QS}$ Yasin/36:17. ${ }^{10} \mathrm{QS}$ al-Baqarah/2:256.

${ }^{11} \mathrm{QS}$ al-Anbiya/21:107.

12 M. Chairil Anwar dan Muhammad Afdillah, Fikrah: Jurnal Ilmu Aqidah dan Studi Keagamaan .v4i1.1621

${ }_{13}$ drd.batangkab.go.id/jurnal/1201609090439470Peran\%2oUlama.pdf

14 Nahed Nuwairah, Dakwah di Tengah Keragaman Umat, Jurnal Ilmu Dakwah Alhadharah Vol.13 No.25, Januari-Juni 2014, h. 15

15 Abersold, G.W., Word to Think About Tolerance of Religion, el Chicano Newspaper, San Bernadino, Calif, 30 Agustus 2012: A 17.

${ }^{16}$ George H. Mead, Mind, Self, and Society (Chicago: University of Chicago Press, 1934), h. 5-10.

${ }^{17}$ George H. Mead, Mind, Self, and Society, h. 10-15

${ }^{18}$ M. Munir, Wahyu Ilahi, Manajemen Dakwah, (Jakarta: Kencana, 2006), Cet. ke-1, h. 21-22.

19Lihat QS al-Nahl/16:125

${ }^{20}$ Lihat Departemen Pendidikan Dan Kebudayaan, Kamus Besar Bahasa Indonesia, (Jakarta: Balai Pustaka, 1999), Cet. ke-10, h. 1066. 
${ }^{21}$ M. Quraish Shihab, Wawasan AlQur'an, (Bandung: Mizan, 1996), Cet. ke-3, h. 379.

${ }^{22}$ Muhammad Said Ramadhan al-Buthiy, Fiqh al-Sirah, (Beirut: Dar al-Fikr, 1414 H/1993 M), h. 160.

${ }^{23}$ H. A. Suminto, Problematika Dakwah, (Jakarta: Tintamas, 1973), Cet. ke-1, h.114-115.

${ }^{24}$ Burhan Bungin, Penelitian Kualitatif, (Jakarta: Kencana, 2011) Cet. ke-5. h. 264-265.

25Burhan Bungin, Analisis Data Penelitian Kualitatif, (Jakarta: PT.

RajaGrafindo Persada, 2012) Cet. ke8. H. 85-87.

${ }^{26}$ Tangsel, "Profil Kota Tangsel", dalam http://www.kemendagri.go.id/pages/ profildaerah/kabupaten/id/36/name/ banten/detail/3674/kotatangerangselatan, diakses pada 8 October 2017.

${ }_{27}$ Badan Pusat Statistik Kota Depok, Kota Depok dalam Angka 2013/2014. Depok: BPS Kota Depok, 214. Pada http://fpksdepok.org/wpcontent/uploads/2015/o6/DDA20132014.pdf, diunduh dan diakses pada 1 Oktober 2017.

${ }^{28}$ Peraturan Menteri Agama dan Menteri Dalam Negeri No. 9 Tahun 2006 dan No. 8 Tahun 2006 tentang Pedoman Pelaksanaan Tugas Kepala Daerah dalam Pemeliharaan Kerukunan Umat Beragama, Pemberdayaan Forum Kerukunan Umat Beragama dan Pendirian Rumah Ibadat

\section{Daftar Pustaka}

Arnold, Thomas W.Sejarah Da'wah Islam. Jakarta: Widjaya, 1981. Cet. ke2.

Bungin, Burhan. Penelitian Kualitatif. Jakarta: Kencana, 2011. Cet. ke-5. Analisis Data

Penelitian Kualitatif. Jakarta: PT. RajaGrafindo Persada, 2012. Cet. ke-8.
Departemen Pendidikan Dan

Kebudayaan. Kamus Besar Bahasa Indonesia. Jakarta: Balai Pustaka, 1999. Cet. ke-10.

Erman, Toleransi Perspektif Piagam Madinah, jurnal Toleransi media ilmiah komunikasi umat beragama, Vol. 3 No. 2, Juli-Desember 2011, diakses dari ejournal.uin-suska.ac.id pada 27 Mei 2016

Kementerian Agama RI, Direktorat Jenderal Bimbingan Masyarakat Islam, Direktorat Urusan Agama Islam Dan Pembinaan Syariah, Al-Qur'an Dan Terjemahnya. Jakarta: PT TEHAZED, 2010.

Mead, George H. Mind, Self, and Society. Chicago: University of Chicago Press, 1934.

M. Munir, Wahyu Ilahi, Manajemen Dakwah. Jakarta: Kencana, 2006. Cet. ke-1.

Nuwairah, Nahed. Dakwah di Tengah Keragaman Umat, Jurnal Ilmu Dakwah Alhadharah Vol.13 No.25, Januari-Juni 2014.

Qardhawi, Yusuf. Minoritas Non Muslim. Bandung: Mizan, 1985. Cet. ke1.

Shihab, M. Quraish. Wawasan AlQur'an. Bandung: Mizan, 1996. Cet. ke3 .

Ramadhan, Muhammad Saidal-Buthiy. Fiqh al-Sirah. Beirut: Dar al-Fikr, 1414 H/1993 M.

Suminto, H. A. Problematika Dakwah. Jakarta: Tintamas, 1973. Cet. ke-1. 
Siradj, Said Aqil. Mamang Muhamad Haerudin, Berkah Islam Indonesia: Jalan Dakwah Rahmatan Lil 'alamin. Jakarta: PT Elex Media Komputindo, 2015. Cet. ke-1.

G.W., Abersold. Word to Think About Tolerance of Religion, el-Chicano Newspaper, San Bernadino, Calif, 30 Agustus 2012: A 17.

Yasir, Muhammad. "Makna Toleransi dalam al-Qur'an" jurnal ushuluddin Vol. XXII No. 2, Juli 2014. Diakses pada 27 Mei 2016 